\title{
The Portrayal of Disaster in Western Fine Art
}

\author{
David E. Alexander
}

Institute for Risk and Disaster Reduction

University College London

Gower Street, London WC1E 6BT, United Kingdom

david.alexander@ucl.ac.uk

Tel: +44 (0) 2031081108

Mobile: +44 (0)744 9657482 
Abstract. This paper offers a survey of how disaster has been depicted in Western art over the centuries. Particular emphasis is placed on the Italian tradition, as Italy is a country that has a rich experience of both artistic developments and disasters and has therefore led the field and provided inspiration to artists from other countries. The survey begins with a few words on Classical art and moves on to a consideration of the Mediaeval fresco tradition. The vision of disaster was expanded when naturalism was introduced into art during the Renaissance. Whereas earthquakes had been a prime motivation for artistic representations in the Mediaeval period, during the Baroque volcanic eruptions seem to have been more popular, especially given the remarkable concentration of artistic output around Mount Vesuvius in the 18th century. Throughout this time, marine painters concentrated on the effects of storm and shipwreck, but often with interesting delineations of extreme atmospheric phenomena. In the 19th century moralism was expressed in the canvasses of John Martin and other painters of the Apocalypse. In the 20th century, Expressionism favoured the lively depiction of scenes involving disaster or natural hazards and so, surprisingly, did certain forms of metaphysical abstraction. In conclusion, disaster has been seen in the Western tradition of fine art in six ways: as spectacle, as allegory (through Classical mythology or Biblical drama), as a votive instrument of atonement, as a visual commemoration of an extreme event, and as a dramatization of a metaphysical proposition.

Keywords. Disaster, Fine art, Painting, drawing and print-making, Art history, Western civilisation. 


\section{Introduction}

Disaster is part of the human condition. For survivors it is a milestone in their lives, while for society as a whole it has variously been interpreted as a judgement, a penance, a demonstration of weakness or vulnerability, a wake-up call, and an opportunity for heroism or altruism. In this context, disaster can reveal the inner workings of society and hold them up to scrutiny (Perry and Quarantelli 2005). So, of course, can fine art (Dissanayake 2008). However, it is remarkable how little Western painters, sculptors and print-makers have engaged with disaster over the last two and a half millennia. Rarely is calamity a theme in art, especially compared to other violent phenomena such as conflict and warfare. In this paper I consider the ways in which artists in the Western world have portrayed disaster from Mediaeval times until the present. Then I consider why calamity and catastrophe have not caught their imagination more often. Such is the richness and variety of Western art that I can make no claim to provide a comprehensive survey. Hence my view is rather more personal than it is authoritative. Nevertheless, there are some trends and recurrent themes that bear scrutiny. No doubt, a rich vein of enquiry runs through oriental art, but it probably needs to be considered separately, as it seems that the principal influence of artistic developments in Asia upon those in the West lies in the inspiration created by order and harmony, not violent destruction.

\section{The Classical period}

The dominant themes in Classical art were symmetry, harmony, perfection and power. The struggles of the gods were very much those of ordinary mortals, but elevated to Olympian levels and graced with special powers. In this there was little scope to deal with the chaos brought by disaster and, it seems, little appetite to commemorate it in 
figurative representations. An exception to this rule, often mentioned, is a marble frieze from the Lararium in the House of Lucius Caecilius lucundus at Pompeii, which appears to show how the earthquake of 5 February AD 62 damaged the Vesuvius Gate, the Aquarium of Cesar and the Capitolium, or Temple of Jupiter, by causing their foundations to fail. Despite the naturalism introduced into the later styles of Pompeiian painting, Mount Somma (the proto-Vesuvius) loomed over the settlements of the Bay of Naples but hardly appeared at all in artistic rendering. Hence, the "last days of Pompeii" had to wait until the Romantic period before they appeared on canvas—and then in highly embellished form.

\section{The Mediaeval period}

Mediaeval painting in Italy occasionally represented natural disaster. There were two main ways in which this occurred. One was votive. For example, in a village on the Po River floodplain near Mantua (northern Italy), in the 15th century an anonymous frescoist painted fishermen in their boats passing down the main street, while people in their houses looked on. The Madonna looks on from the clouds, and various saints pray for the salvation of the victims. The other style involved using natural hazards as illustrations for biblical scenes. For instance, in 1447-8 the celebrated Tuscan painter Paolo Uccello (1397-1475) completed a fresco cycle in the Green Cloister (Chiostro Verde) of Santa Maria Novella in Florence which showed the story of Noah and the Universal Deluge, with flood scenes in the lunettes.

Floods appeared comparatively rarely in Italian painting, but earthquakes were much more common. Once again, they tended to be linked to biblical stories. A 14th century fresco by a follower of Giotto that can be found in the north transept of the Lower Basilica at Assisi is said to show the miraculous revival of a child killed by an 
earthquake. This work, 'Death of the Suessa Child', was painted in 1313, and the expressions seem, more dramatically, to show the grief of his mother and relatives at his death rather than his survival. During the 14th century there were seven damaging earthquakes in central Italy, with perhaps as many as 8,000 deaths (Guidoboni and Comastri 2005). Hence, it is not surprising that they impinged upon the consciousness of some of the many artists at work there at the time. In 1367, in the Collegiate Church of St Mary of the Assumption, San Gimignano (Tuscany), Bartolo di Fredi (1330-1410) completed his fresco of 'The Fall of the House of Job', which vividly depicts structural collapse onto a group of 14 hapless victims. While this work does not directly invoke earthquakes (in fact, Job 1:19 speaks of a windstorm), we may speculate that Bartolo may have been influenced by the Sienese earthquake of 1361 , which had an estimated magnitude of 5.0 .

Another frescoist, Andrea di Cione di Arcangelo (Andrea Orcagna, c. 1308-68) painted the Triumph of Death in 1367 In the chancel of Santa Croce in Florence. He himself died from alcoholism in 1368 before it was completed and the work was eventually covered up until fragments of it were rediscovered in 1942. It appears that he drew his inspiration from two contemporary scourges: the Black Death and earthquakes (Koppenleitner 2010, p. 89).

In the Church of the Incorontata in Naples, a follower of Giotto da Bondone (1335-82) depicted Sampson and the destruction of the temple of the Philistines (Judges 16:30) in a manner that puts one in mind of the structural collapses caused by earthquakes. The death of Christ is strongly bound up with the allegory of earthquakes, as indicated in Matthew (27:51): "And behold, the veil of the temple was torn in two from top to bottom; and the earth shook and the rocks were split." However, most artistic renderings of the death of Christ in the mediaeval and Renaissance periods 
evoked calm and mysticism rather than apocalypse, as they were designed to prepare the mind for the Resurrection.

Another important fresco from the Mediaeval period was the Fall of Ephesus by Pietro da Rimini (d. 1345), in the church of Sant'Agostino in Rimini. The work shows a church campanile collapsing amid massive destruction. Ephesus, briefly the home of St Paul, suffered major earthquakes in AD 23 and 262: Rimini in 1308 (Guidoboni and Comastri 2005). Koppenleitner (2010, p. 94) speculated that Pietro may have painted from experience. Whether or not that was the case, those church frescoes of the mediaeval period which showed the destruction of architecture were meant to symbolise the vanquishing of the pagan world and its replacement with the Christian one (ibid., pp. 98-101).

\section{The Renaissance}

These traits continued into the Renaissance. There is no more brilliant demonstration of this point than the fresco cycle of the 'Destruction of the Temple', with which in the late 1520s Giulio Romano (1499-1546) adorned the Hall of the Giants, one of the rooms of Palazzo del Tè in Mantua. Here the religious iconography has been aggressively supplanted by one drawn from Classical mythology. However, wind rather than earth tremors is the vehicle of destruction, and, while the gods can narrowly resist it, the temple cannot. The theme of the death of Samson remained a popular one in art for centuries afterwards, as can be seen in a monumental engraving made in 1865 by Gustave Doré (1832-83).

With the rise of naturalism in painting, there was a growing tendency to depict the violence of nature more graphically and in a less stylised form, albeit as a backdrop to scenes of human drama. A good example is visible in a canvas by the Venetian 
painter Giorgio Barbarelli ('Giorgione', 1477-1510) in which a thunderstorm rumbles over the towers and coppices of the terrafirma. This painting, 'The Tempest', has been described as the first real landscape in the history of Western painting (Büttner 2006, pp. 74-77). It is heavy with symbolism and contrast. A woman breastfeeds a baby while a man looks on. The landscape of the foreground is tranquil, while that of the background is storm-tossed. While disaster is no more than a hint in such a work, the symbolism of unresolved conflicts is a very pertinent iconography.

No work of art in the Western tradition of the Renaissance more accuratelyand dramatically — portrays the nature of flooding that do the studies of water made by Leonardo da Vinci (1452-1519) over the period 1508-15 and now in the UK Royal Collection at Windsor Castle. Leonardo was known and revered for his paintings, which emanated tranquillity. However, he was interested in both flood control and the ways in which the Universal Deluge had apparently created the elevated banks of marine fossils that can be found in the Plio-Pleistocene sediments of Tuscany. Hence he extrapolated his remarkably precise observations of small-scale turbulence to the scale of an entire landscape. Doing so led him to question the veracity of the Deluge and speculate on uplift of the land (Alexander 1982, p. 750). Yet Leonardo was afraid of persecution for heresy and kept his notebooks away from public scrutiny (indeed, scholars have presumed that he used his ambidexterity to write in both directions so that his personal notes would not easily be read by prying eyes, Shlain 2014). It was not until 1850 that Leonardo's codices were rediscovered and began to be appreciated: as a scientist he was truly centuries ahead of his time.

At this point it is worth making an aside in order to discuss a painting by Raffaello Sanzio (1483-1520), which is known as the 'Madonna of the Goldfinch'. The work, which does not depict anything related to disaster, was completed in 1506 and given 
as a wedding present to Raphael's friend Lorenzo Nasi. On 17 November 1548 it was broken into 17 fragments when Nasi's house collapsed in a seismically-induced landslide. It was salvaged and hastily repaired, but not properly restored until 2002 (Falvo 2014).

\section{The Baroque and 19th Century}

The theme of fire has long occupied painters. For example, in 1666 there were various representations on canvas and paper of the Great Fire of London. However, it was not until the Houses of Parliament caught fire in 1834 that a master painter depicted the scene. This was Joseph Mallord William Turner (1775-1851), who set up his easel at the southwest corner of Westminster Bridge, and then again further downstream. Turner was a compulsive painter and his hyperactivity stood him in good stead as he managed to dash off two excellent canvasses before the flames were extinguished.

Meanwhile, another phenomenon related to fire was to occupy the minds, and the brushes, of painters for almost three centuries: the eruption of Mount Vesuvius. The eruptive sequence began in 1631 with a massive nuée ardente, which rolled down the mountain from the central vent into the town of Portici, where it incinerated 4,000 inhabitants, or well-nigh the entire population. The scene was observed from San

Giovanni a Teduccio, 5 km away, by Domenico Gargiulo (1609-75), who made a remarkably realistic painting in oils of the disaster, which shows the nuée rolling down the mountain while the population of Naples comes out to observe the unfolding spectacle from the piazzas and rooftops. In keeping with the votive tradition, St Jannarus flies above the streets on a cloud occupied by a gaggle of putti as he bids the volcano not to overrun Naples. 
Although nothing of the entity of the Plinian event of AD 79 occurred between 1631 and 1904, in this period Vesuvius was more or less continuously in eruption. No more than seven years went by without exhalations of gas, ash and lava. For the nobility of Naples and Grand Tourists from the rest of Europe, the spectacle was irresistible, especially at night. While in the 20th century there were only two eruptive phases (1906 and 1943-4), in the 18th and 19th centuries there were 13 and 19, respectively, of which the largest and most destructive occurred in 1794 (Scandone et al. 2008).

An entire colony of minor and jobbing artists came into being on the shores of the Gulf of Naples, dedicated to painting, with varying degrees of realism and skill, the high points of the eruptions. Their medium of choice was gouache, a form of waterbased paint that could represent the strong colours of the eruption better than watercolours were able to do. Occasionally, local artists of much higher stature became involved, such as Pietro Fabris (1740-92). His depiction, in 1761, of a'a lava coursing from two flank cones across fruit orchards towards Torre del Greco is justly renowned.

When, in 1606, Michelangelo Merisi da Caravaggio (1571-1610) killed a man in a duel in Rome, he fled to Naples. Although his stay was short (he moved on to Malta), he completed some important commissions and imbued the Neapolitans with a love of his characteristic chiaroscuro style, something of which can be seen in, for example, the storm-tossed perspectives of Salvator Rosa (1615-73). Into this milieu came Joseph Wright of Derby (1734-97), the English master of chiaroscuro, who painted several views of Vesuvius by night. His oeuvre includes a remarkably impressionistic oil sketch of lava coursing across the landscape from the central vent, as seen at deep 
twilight. Wright had made something of a speciality of painting iron foundry scenes by night was easily about to transfer his technique to nocturnal eruptions.

Other English artists who arrived to paint Vesuvius during its liveliest period included William Marlowe (1740-1813) and William Hodges (1744-97). By dint of imagination combined with observation, the latter managed a remarkably realistic bird's-eye view of the central crater with lava and fumaroles. In 1817 Turner came to paint a nocturnal view of a minor eruption. As in so many of his continental works, he used watercolour, but he thickened it with gum in order to represent the darkness of night and contrasting spouts of flame. In much the same way as the English, German artists were assiduous frequenters of the Bay of Naples. For example, Jakob Philipp Hackert (1737-1807) captured the nocturnal effects of major eruptions over the period 1786-99, when he enjoyed the patronage of Ferdinand I of the Two Sicilies. He was on hand to paint the great eruption of 1794 .

During the 18th century painters tended to see Vesuvius as a gigantic fireworks show rather than a source of death and destruction. As the 19th century wore on, the approach was progressively refined towards even greater demonstrations of romanticism. The Italian painter Alessandro La Volpe (1819-87) depicted Vesuvius in the full romantic tradition bathed in the roseate light of sunset, and quiescent rather than in paroxysm. Finally, the German painter Oswald Achenbach (1827-1905) produced a very fashionable view from Terzigno to the east, one that anticipated the fin du siecle style. An aedicule of St Jannarus raises a restraining hand towards the vertical blast and steaming trails of lava emanating from the mountain in the background, while well-dressed Neapolitans promenade on the piperno lava cobbles in the foreground. 
Discussion of Vesuvius in the context of painting would not be complete without mention of painters' efforts to depict the destruction of ancient Pompeii. The buried city was first encountered in 1599, but excavations did not get underway until 1748 under the direction of the Spanish military engineer Rocque Joaquin de Alcubierre (Özgenel 2008, pp 9-10).

In 1834 the English baron Edward Bulwer-Lytton (1803-73) published his novel The Last Days of Pompeii (Bulwer-Lytton 1834), which he had been inspired to write after he had seen a painting of the same name that the Russian artist Karl Briullov (1799-1852) had completed in 1833 and had exhibited in Milan. It was, moreover, his best-known work, but it was by no means unique. Indeed, only 12 years after excavation of Pompeii had begun in earnest, the Parisian artist Hubert Robert (17331808) visited them and painted a visions of the destruction of the town and one of the Fire of Rome, AD64. In these, in characteristic manner, fire and classical architecture are combined as the backdrop to a human drama in which the people are dwarfed by the enormity of the event-if not the enormity of the architecture as well, for it is thoroughly out of scale! The Italians were not to be outdone. An aquatint with remarkably similar properties was painted by the little-known artist Carlo Sanquirico (active 1820-39), who was related to Alessandro Sanquirico (1777-1849), the scenographer of Teatro La Scala in Milan. The connection is relevant in that the latter artist produced the scenery for the Milan production of Giovanni Pacini's operatic extravaganza L'ultimo giorno di Pompei ('The Last Day of Pompeii'), which was first performed in Naples in 1825 (Sanquirico c 1830).

It should be noted that Vesuvius was not the only volcano to be painted while in eruption. The doyen of the Hudson River School, Frederic Edwin Church (1826-1900) loved to paint atmospheric effects in grand landscapes. Most of these were heroic but 
pacific, for example, his views of Niagara Falls and of the Aurora Borealis. In 1862 he visited Mexico and painted Cotopaxi in eruption, but more in the sense of the wonders of nature than of death and destruction. A gorge and cataract occupy the foreground, offering a reference to the canvas of Niagara he had painted five years previously.

Towards the end of the Baroque period, a disaster occurred that had a profound impact on European culture. This was the Lisbon earthquake (Alexander 2002, Chester 2001, Dynes 2000, França 1983). João Glama Strobërle (1708-92) was a Portuguese artist of German extraction and Italian training. His most famous work is a large votive-allegorical canvas of the ruins and survivors of the earthquake. It includes a small vignette of himself looking better dressed and more in control than any of the other people in the view. Above in the sky, the Angel of Retribution flashes a sword, mitigated by another angel who proffers a sign of peace. The Lisbon earthquake, tsunami and fire came at a time of considerable upheaval and transition in the economic, social and intellectual life of Europe (Shrady 2009). It threw the Enlightenment into reverse gear (Dynes 2000) and gave considerable scope to those who would make fun of the sententiousness of establishment figures. François Voltaire did so brilliantly in Candide, by turning the tables and using allegory against the reactionaries rather than to support their policies, as the Church did. (Voltaire 2006).

Many minor artists whose names have not been recorded sought to depict the moment of the Lisbon earthquake and the ruination that it caused. Their works vary from the fanciful to the accurate, from gross approximation to careful accuracy, and the artistic impulse continued for a century afterwards. Given that photography was the better part of a century away from being invented, a record of the situation was required. Etchings of the ruins, and the rebuilding, were circulated around Europe. These folios did not shrink from showing the full anatomy of the destruction, or some 
of the punishments meted out to the survivors, who were executed by hanging if they transgressed from the rules set by the architect of the recovery, Sebastião José de Carvalho e Melo, 1st Marquis of Pombal (1699-1782). He was de facto the Viceroy of Portugal during the period after the disaster. The Lisbon earthquake may have thrown the Enlightenment into disarray, but Pombal ensured that he would go down in history as the man who finally brought it to Portugal, which had before been struggling to emerge from the Mediaeval straitjacket of the Inquisition (Shrady 2009). In 1766, Pombal commissioned two very fashionable French painters to record his efforts to rebuild Lisbon: Louis-Michel van Loo (1707-71) and Claude Joseph Vernet (1714-89). Like Turner, the latter has specialised in paintings of storms and shipwrecks. This time, the effects were quite different. Pombal's hand makes the grand gesture towards a harbour thronged with ships, a waterfront full of reconstructed buildings and a baroque stool on which complex technical plans have been strewn with nonchalant grace.

\section{Towards Victorian culture}

It was perhaps not the Lisbon earthquake but Victorian moralism which led to the popularity of John Martin (1789-1854). A painter in oils from northern England with a penchant for the grand canvas, he produced some small pictures of rural domestic peace, but his main output consisted of a series of panoramic visions of the Apocalypse. There were many of these and the details were usually inspired by Nordic mythology or Classical monuments. They depicted earthquakes, landslides, storms, lightning, violent winds, torrential rain and, in one case, a meteorite shower. His most famous work is 'The Great Day of His Wrath' (c. 1853), which hangs in London's Tate Britain Gallery. Martin loved to paint people as tiny figures overwhelmed by the vast forces of nature, behind which the Hand of a wrathful God can be detected. Martin's 
vision was briefly emulated by Samuel Coleman (1832-1920), an American landscape painter of the Hudson River School. In one of his canvasses ('The Destruction of the Temple', 1830-40) precisely drawn Gothic architecture is destroyed by fire, while a pathetic group of survivors huddles together in the foreground. This work manages to combine the Mediaeval preoccupation with dismantling paganism and Martin's high Victorian story of moral retribution.

Another artist whose mystical romanticism inclined him towards apocalyptic visions was the Swiss painter Arnold Böcklin (1827-1901). He is well-known for the slightly morbid 'Isle of the Dead' (1883), which, however, is a landscape of peace in a moribund sort of way. However, his other works include several that combine ruins with turbulent atmospheric effects in a manner that invokes the frustration of human aspirations.

J.M.W. Turner is perhaps the greatest of marine painters and many of his canvasses depict storms at sea, in which ships are torn apart and mariners struggle to avoid drowning. At their most tempestuous, these paintings verge upon the apocalyptic, although more with a sense of heroism than the moral reprobation that hangs so heavily over the work of John Martin. Turner's journey to Italy was heroic in its own right, and it led to a series of paintings of Alpine scenery in all conditions of nature. One of these, sketched in Graubünden in 1810, shows a snow avalanche accompanied by a rockfall, with powdered snow swept up in a characteristic air-blast. The painting is remarkable for the detachment with which this alarming scenario is observed. Pine trees are smashed by rocks and houses are at risk. The dynamics of the scene, as expressed in the geometry of the painting, are strongly reminiscent of Turner's views of storms at sea. 
Another 19th century painter with a sense of the dramatic was Peder Balke (1804-87), many of whose views of the northern Norwegian coast are dark with foreboding and lashed by rain, wind and waves. Further south in Europe, storm and shipwreck feature most dramatically in a painting called 'The Deluge' by the English artist James Francis Danby (1816-75), described—with allusion to John Martin—by Wood (1999, p. 20) as "the largest and most dramatic of his Martinesque visions." In this work, a storm at sea, and consequent shipwreck are transformed into a partial allegory of the Universal Deluge, again with the high Victorian aura of judgement and retribution. Similar feelings are invoked by other artists' paintings of the Universal Deluge, which was a theme tackled by Turner, Doré and Nicholas Poussin (15941665).

A more measured, naturalistic painter was William Hodges (1744-97), who had studied with Richard Wilson in North Wales, and participated in Captain James Cook's second voyage of discovery to the Southern Hemisphere. Upon his return in 1776 the British Admiralty paid him to turn his sketches into oil paintings. One of these shows Cape Stephens in Cook's Straits, New Zealand, as a coastal scene with four waterspouts. Although there are hints of the waterspout in Turner's more animated paintings, in this case the phenomenon is transferred to canvas with a rare literalness. The same can be said of a work by the Polish landscape artist Ferdynand Ruszczyc (1870-1936) who in 1901 painted a heath with figures and in the background no fewer than nine tornadoes. The depiction is meteorologically correct and the painting comes from a time when interest in the science of tornadoes was just beginning to awaken (Murphy 1996).

Like Turner, the Russian painter Ivan Konstantinovich Aivazovsky (1817-1900) is considered to be one of the greatest of all marine artists (Caffiero and Samarine 
2013). He specialised in cold, windy seascapes, and some of his paintings dramatize the scene with ship disasters, such as explosions and fires (e.g. 'Crash', 1876; 'Exploding Ship' 1900). In similar vein the American portraitist William Ruthven Wheeler (1832-94) had painted a ship being destroyed by fire on one of the Great Lakes, while the crew row away in a lifeboat. Continuing the tradition, Winslow Homer (1836-1910), another American artist with a penchant for lively seascapes, painted a winch rescue from a ship in trouble ('The Life Line', 1889). Finally among coastal scenes and seascapes, in 1861, a painter of vernacular scenes from northern England, John Charlton (1849-1917), produced a remarkable work called 'The Women', which shows a large group of women dragging out the lifeboat at Cullercoats (Tyne and Wear) into the agitated seawater on the coast of northeast England. Charlton was a contemporary of Stanhope Alexander Forbes (1857-1947), who used vernacular narrative painting to popularise the life of fisher people and coastal communities but never produced anything as dramatic and rhetorical as 'The Women.'

The Austrian painter Eugene Von Guérard (1811-1901) emigrated to Australia in 1852 and five years later produced a panoramic view of a large bushfire that owes much to the grand style of colonial painting. Wildfire has been a much less popular theme among artists than has fire in urban environments, but one who repeatedly depicted it was the Russian landscape artist Alexei Denisov Kuzmich (1863-1926), who in 1897 painted a fire in the taiga in a manner that is both lively and realistic (Budrina, 2015). In the next century, the quintessentially Australian artist Sidney Nolan (1917-92) produced an allegorical canvas of drought and the abandonment of farms, a common scourge of rural life Down Under.

\section{The 20th century}


Other forms of natural hazard occasionally appear in the record of Western painting. For example, Claude Monet's (1840-1926) painting 'The Church at Varengeville, Morning' shows rockfall from a coastal cliff. By virtue of his very characteristic impasto technique, Monet's fellow Frenchman, Maurice de Vlaminck (1876-1958), was the past-master of depicting snow and intense cold. However, no one could convey in painting the intensity of extreme cold as could the Russian landscape artists. Among these Julius von Klever (1850-1924), of Baltic German descent, painted several coastal scenes that convey the full force of sub-zero temperatures (e.g. 'Winter Landscape', 1881).

In the 20th century the focus, philosophy, techniques and objectives of painting changed radically. For the most part, gone were the narrative canvasses of the previous century. Abstraction and metaphysical considerations came in. This left little room for the literal depiction of disaster. Nevertheless, two paintings in a series by the Belgian surrealist René Magritte (1898-1967) show, respectively, a storm and a burning house, both as part of a more complex philosophical tableau. In an entirely different vein, partial abstraction allowed the Dutch graphic artist Maurits Cornelis Escher (1898-1972) to find symmetry in a storm at sea, something that marine artists have deliberately eschewed.

More than 20 countries of the world are classed as highly seismic, but it is singular how rarely earthquake appear in fine art. One artist who has engaged with them is the Colombian painter and sculptor Fernando Botero (1932- ) who has produced various paintings of seismic disasters, including one of a post-earthquake funeral procession amid the cracked and leaning houses. He adapted his earthquake view in a painting of the explosion of a car bomb, which is depicted unflinchingly, as are all his paintings of torture, organised crime and gang violence. Perhaps the only 
European equivalent can be found in the paintings of Second World War artists such as John Armstrong (1893-1973) and John Piper (1903-92), who faithfully delineated the ruins of buildings destroyed by the bombs. These in turn send us back to the work of earlier painters, such as Bernardo Bellotto (1721-80), who in 1765 painted the combination of war damage and structural collapse at the Kreuzkirche in Dresden.

Finally, modern painters have returned to the subject of volcanoes in eruption. The Sicilian maestro Renato Guttuso (1912-87) produced some richly expressionistic views of Stromboli and Etna streaming with lava and girdled by ash-clouds. Last of all, in marked contrast to what had gone before, 1985 saw the American pop artist Andy Warhol (1928-87) produce a series of colourful screen-prints that are recognisably of Vesuvius in eruption. The mood, however, is satirical rather than awe-inspired, as the choice of colours and heavy stylisation attest. This is Vesuvius as soda-syphon, a flat spectacle destined for the television screen, not for the contemplation of existential problems.

\section{Concluding discussion}

In this survey of Western art there is a heavy emphasis on Italy. This is because it was for centuries the crucible of innovation, with an artistic tradition that was richer, livelier and adapting more rapidly than that of most other countries. Moreover, Italy bears a heavier burden of natural hazards than does most of the rest of Europe, a fact that could hardly avoid impinging upon the consciousness of artists working there. Nevertheless, as time wore on, artists elsewhere in the Western world began to be interested in depicting catastrophe. In some cases, such as the long sequence of eruptions of Vesuvius, they saw it as an opportunity for expression; in others, it impinged upon their work by sheer force of circumstance. 
In preparing this essay, I have scrutinised more than 40,000 paintings, drawings and prints in search of the elements of disaster. It is present in remarkably few of them, which is testimony to the fact that artists tended to prefer beauty and harmony to chaos and destruction, or at least they preferred the heroism of war to the impersonal depredations of calamity, whether of natural or man-made origin.

In the works of art that do tackle the theme of disaster, or at least its causative agents, there are six possible themes. The first is disaster as spectacle, especially where it overwhelms people and demonstrates the dominance of nature (and, by association, the Almighty) over the human race. Small figures huddle in front of a mighty panorama of atmospheric effects, or are dashed on the rocks by shipwreck in a highly agitated sea. A vast curtain of flames leaps towards the sky; gigantic rocks tumble towards the valley bottom. Secondly disaster is treated as allegory, sent from above to remind us, not only of our frailty and impermanence, but also of out tendency to err and to sin. This is the realm of Classical mythology or Biblical drama, as in the work of John Martin or Giulio Romano, two painters of markedly different times and temperaments who are linked by the common allegorical thread. Similarly, the third theme is the depiction of disaster in a votive capacity in order to offer atonement for the sins that provoked it. Strobërle's painting of the Lisbon earthquake is a fine example of this, with the avenging angel's sword of retribution raised in the sky above the ruined buildings and desperate population.

Fourthly, simpler interpretations of disaster include visual commemoration of great events, sometimes with a narrative content. The 1666 Fire of London, the 1755 Lisbon earthquake and the 1794 eruption of Vesuvius were all treated in this manner. Fifthly, from Leonardo to Turner there have been depictions of violent physical phenomena in their own right as objects or situations worthy of curiosity. These were 
relatively rare, but from the Enlightenment to the age of scientific exploration disaster was-perhaps reluctantly_included in the portfolio of phenomena to depict. Sixthly and finally, an even rarer category is that of abstracted metaphysical views of disaster, such as those of Magritte and Warhol.

In conclusion, I reiterate my caveat lector that this essay cannot include all the relevant fruits of artistic endeavour. Nor does it look to the future, in which there may well be a revival of interest in disaster on the part of painters and print-makers. Alternatively, there may be new directions. In Japan after the earthquake and tsunami of March 2011, art has been used as a form of protest and a means of criticising politicians and the Japanese establishment (Brown and Mackie 2015). It is perfectly capable of fulfilling this role in other countries.

I would like to end with two of the oldest concepts in Western civilisation: the Platonic notions of generatio and corruptio, creation and destruction. The Greeks had intended these primarily as expressions of small-scale cycles, by which, for example, mountains were elevated and their rocks gradually shattered and scoured away by erosion. The Mediaeval thinker, however, was apt to impose a beginning and an end to the great cycles, and hence generatio gradually became equated with Genesis, and corruptio with the Day of Judgement and the ensuing extinction of the world in a final conflagration. Greeks who had been sceptical of Plato had interpreted the magnus annus, or the world's 'Great Year' of existence in this way, as one phase of growth and decay (Adams 1938). To some extent, these concepts underpin much of the pictorial representation of disaster in the centuries before the invention of photography. From a difficult, painful birth, to an apocalyptic end, the human experience was mediated by disaster. 


\section{Appendix: Paintings cited in this article}

Artists ad paintings are given in the order in which they are cited, with the location of the painting (where known) and the Web address of a reproduction or article.

Anon.

Marble frieze of earthquake damage, post-AD 62

Lararium in the House of Lucius Caecilius lucundus, Pompeii

https://sites.google.com/site/ad79eruption/pompeii/regio-v/reg-v-ins-1/house-of-I-caecilius-jucundus

Paolo Uccello (1397-1475)

Fresco: "Flood and Waters Subsiding", 1447-8

Green Cloister (Chiostro Verde), Santa Maria Novella Convent, Florence

http://www.wga.hu/html_m/u/uccello/1green/

Follower of Giotto or Cimabue

Fresco: "Death of the Suessa Child", 1313

North transept of the Lower Basilica, Assisi

http://www.context.magic-nation.co.uk/assisi17.htm

Bartolo di Fredi (1330-1410)

Fresco: "The House of Job Falls on his Children", 1367

Collegiate Church of St Mary of the Assumption, San Gimignano (Tuscany)

https://commons.wikimedia.org/wiki/File:SG_OT_The_house_of_Job_falls_on_his_children_Bartolo_di _Fredi.jpg

Andrea di Cione di Arcangelo (Andrea Orcagna, c. 1308-68)

Fresco: "Triumph of Death", 1367

Chancel of Santa Croce, Florence

https://commons.wikimedia.org/wiki/Category:Andrea_Orcagna

Roberto d'Oderisio (1335-82)

Fresco: "Sampson and the Destruction of the Temple of the Philistines", 1340-3

Santa Maria Incorontata, Naples

https://www.flickr.com/photos/70125105@N06/22608876381

Pietro da Rimini (d. 1345)

Fresco: "Fall of Ephesus", c. 1315-35

Church of Sant'Agostino, Rimini

https://commons.wikimedia.org/wiki/File:Pietro_da_rimini,_crollo_di_efeso_e_martirio_di_s._giovanni_ nell'olio_bollente,_xiv_sec._02.jpg

Giulio Romano (1499-1546)

Fresco cycle: "Destruction of the Temple", late 1520s

Hall of the Giants, Palazzo del Tè, Mantua

http://wtfarthistory.com/post/17154746853/reign-of-the-giants

Gustave Doré (1832-83)

Etching: "Death of Samson",1865

http://www.wikiart.org/en/gustave-dore/death-of-samson-1866

Giorgio Barbarelli ('Giorgione', 1477-1510) 
Painting: "The Tempest", 1506-8

Gallerie dell'Accademia, Venice

https://en.wikipedia.org/wiki/The_Tempest_\%28Giorgione\%29

Leonardo da Vinci (1452-1519)

Drawings: Studies of water, 1508-15

UK Royal Collection, Windsor Castle

http://witcombe.sbc.edu/water/artleonardo.html

Raffaello Sanzio (Raphael, 1483-1520)

Painting: "Madonna of the Goldfinch", 1506

Uffizi Gallery, Florence

https://en.wikipedia.org/wiki/Madonna_del_cardellino

Joseph Mallord William Turner (1775-1851)

Paintings: "Fire at the Houses of Parliament", 1834-5

Tate Britain, London, Philadelphia Museum of Art, and other locations

http://www.tate.org.uk/art/artworks/turner-the-burning-of-the-houses-of-parliament-d36235

http://www.philamuseum.org/collections/permanent/103831.html

Domenico Gargiulo ('Micco Spadaro', 1609-75)

Painting: "Processione di S. Gennaro per l'eruzione del 1631", 1631

Private collection.

https://commons.wikimedia.org/wiki/File:Spadaro_eruzione_vesuvio.jpg

Pietro Fabris (1740-92)

Painting: "La colata di lava del Vesuvio verso Resina, l'11 maggio 1771", 1771

Private collection.

http://www.vesuvioweb.com/it/2014/11/palazzo-dellinglese-vesuvio/

Joseph Wright of Derby (1734-97)

Paintings: "Vesuvius in Eruption by Night", 1773-5

Huntington Library, San Marino, California; Tate Britain, London: Yale Center for

British Art, Newhaven, Connecticut

https://en.wikipedia.org/wiki/Vesuvius_in_Eruption_\%28Wright_painting\%29

William Marlowe (1740-1813)

Painting: "Vesuvius Eruption at Night", 1768

Berger Collection, Denver, Colorado

https://commons.wikimedia.org/wiki/File:Vesuvius_erupting_at_Night_by_William_Marlow.jpg

William Hodges (1744-97)

Painting: "Inner Crater of Mount Vesuvius", 1775

Royal Pavilion, Brighton and Hove

https://commons.wikimedia.org/wiki/Category:Paintings_by_William_Hodges\#/media/File:William_Hod ges_\%28attrib.\%29_-_The_Inner_Crater_of_Mauna_Loa,_Hawaii.jpg [misattributed]

Joseph Mallord William Turner (1775-1851)

Painting: "Mount Vesuvius in Eruption", 1817-20

Yale Center for British Art, Newhaven, Connecticut

https://commons.wikimedia.org/wiki/File:Joseph_Mallord_William_Turner_-_Vesuvius_in_Eruption_-

_Google_Art_Project.jpg 
Jakob Philipp Hackert (1737-1807)

Paintings: "Vesuvius in Eruption", 1786-99

Private collections.

https://www.flickr.com/photos/32357038@N08/4345134624

Alessandro La Volpe (1819-87)

Painting: "View of the Bay of Naples", 1877

Private Collection

http://fineartamerica.com/featured/view-of-the-bay-of-naples-alessandro-la-volpe.html

Oswald Achenbach (1827-1905)

Painting: "Eruption of Vesuvius", 1882?

Private Collection

https://uk.pinterest.com/pin/562738915909463429/

Karl Briullov (1799-1852)

Painting: "The Last Day of Pompeii", 1833

State Russian Museum, St. Petersburg

https://en.wikipedia.org/wiki/The_Last_Day_of_Pompeiit/media/File:Karl_Brullov_-_The_Last_Day_of_Pompeii__Google_Art_Project.jpg

Hubert Robert (1733-1808)

Painting: "The Fire of Rome of July AD64", 1795

Musée d'art moderne André Malraux, Le Havre

http://art-now-and-then.blogspot.it/2012/03/hubert-robert.html

Carlo Sanquirico (active 1820-39)

Aquatint: "The Last Day of Pompei", 1830

J. Paul Getty Museum, Los Angeles, California

http://thegetty.tumblr.com/post/31429806008/opera-set-for-the-eruption-of-vesuvius-from

Frederic Edwin Church (1826-1900)

Painting: "Cotopaxi", 1862

Detroit Institute of Arts

http://antiquesandfineart.com/articles/media/images/00801-00900/00855/Cotopaxi_1862.jpg

João Glama Strobërle (1708-92)

Painting: "Alegory of the Lisbon Earthquake", c. 1755

Museu Nacional de Arte Antiga, Lisbon

https://commons.wikimedia.org/wiki/File:Alegoria_ao_Terramoto_de_1755,_Jo\%C3\%A3o_Glama_Str ob\%C3\%ABrle.png

Louis-Michel van Loo (1707-71) and Claude Joseph Vernet (1714-89)

Painting: "Marques Pombal", 1766

Museum of the City of Lisbon

https://commons.wikimedia.org/wiki/File:Louis-Michel_van_Loo_003.jpg

John Martin (1789-1854)

'The Great Day of His Wrath', c. 1853

Tate Britain, London

https://en.wikipedia.org/wiki/File:John_Martin_-_The_Great_Day_of_His_Wrath_-

_Google_Art_Project.jpg 
Samuel Coleman (1832-1920)

Painting: "The Destruction of the Temple", 1830-40

Tate Britain, London

http://www.tate.org.uk/art/artworks/colman-the-destruction-of-the-temple-t01980

Arnold Böcklin (1827-1901)

Painting "Isle of the Dead", 1880-6 (various versions)

Alte Nationalgaleri, Berlin

https://en.wikipedia.org/wiki//sle_of_the_Dead_\%28painting\%29

Joseph Mallord William Turner (1775-1851)

Painting: "The Fall of an Avalanche in the Grisons", 1810

Tate Britain, London

http://www.wikiart.org/en/william-turner/the-fall-of-an-avalanche-in-the-grisons

Peder Balke (1804-87)

Painting: "Oprørt hav med et dampskib nær den norske kyst", 1847-50

National Gallery of Denmark, Copenhagen

https://commons.wikimedia.org/wiki/File:Opr\%C3\%B8rt_hav_med_et_dampskib_n\%C3\%A6r_den_nor ske_kyst.jpg

James Francis Danby (1816-75)

Painting: "The Deluge", 1840

Tate Britain, London

https://en.wikipedia.org/wiki/Francis_Danby\#/media/File:Francis_Danby_-_The_Deluge_-

_Google_Art_Project.jpg

Nicolas Poussin 1594-1665

Painting: "L'Hiver ou Le Déluge", 1660-4

Louvre, Paris

http://artintheblood.typepad.com/.a/6a0120a570a392970b013480caf28e970c-pi

William Hodges (1744-97)

Painting: "A View of Cape Stephens in Cook's Straits New Zealand with Waterspout", 1776

UK Ministry of Defence

https://commons.wikimedia.org/wiki/File:HodgesA_View_of_Cape_Stephens_in_Cook's_Straits_New_ Zealand_with_Waterspout_1776..jpg

Ferdynand Ruszczyc (1870-1936)

Painting: "W świat", 1901

Location unknown

http://www.wikiart.org/en/search/Ferdynand\%20Ruszczyc\#supersized-search-321627

Ivan Konstantinovich Aivazovsky (1817-1900)

Painting: "Crash", 1876

Private collection.

https://uk.pinterest.com/pin/553942822897132218/

Painting: "Exploding Ship", 1900

Aivazovsky National Art Gallery, Feodosia, Crimea

https://commons.wikimedia.org/wiki/File:Ivan_Constantinovich_Aivazovsky__Exploding_Ship.jpg 
William Ruthven Wheeler (1832-94)

Painting: "Great Lakes Marine Disaster", 1860

Private collection.

http://americanartgallery.org/uploads/pictures/012109/50d5ee02e1c00.jpg

Winslow Homer (1836-1910)

Painting: "The Life Line", 1889

Philadelphia Museum of Art

http://www.themagazineantiques.com/articles/winslow-homers-the-life-line/

John Charlton (1849-1917)

Painting: "The Women"

Laing Art Gallery, Newcastle

https://uk.pinterest.com/pin/232709505715833488/

Eugene Von Guérard (1811-1901)

Painting: "Bush Fire Between Mount Elephant and Timboon", 1857

Ballarat Fine Art Gallery, Australia

https://commons.wikimedia.org/wiki/File:Eugene_von_Guerard_-

_Bush_fire_between_Mount_Elephant_and_Timboon,_1857.jpg

Alexei Denisov Kuzmich-Uralsky (1863-1926)

Paintings: "The Forest Fire", 1897 et seq.

Sverdlovsk Regional Local History Museum, Yekaterinburg Fine Arts Museum and other locations.

http://elar.urfu.ru/bitstream/10995/31967/4/qr_2_2015_03.pdf

https://uk.pinterest.com/pin/506021708101704621/

Sir Sidney Robert Nolan (1917-92)

Painting: "Drought Skeleton", 1953

New South Wales Art gallery, Sydney

http://www.artgallery.nsw.gov.au/collection/works/229.2002/

Aquatint/etching: "Drought", 1957-8

National Gallery of Victoria, Melbourne

http://www.ngv.vic.gov.au/explore/collection/work/59338/

Claude Monet (1840-1926)

Painting: "The Church at Varengeville", 1882

Private collection.

http://poulwebb.blogspot.it/2013/11/claude-monet-part-12-1881-1882.html

Maurice de Vlaminck (1876-1958)

Painting: "Rue de village sous la neige"

Private collection.

http://www.artvalue.com/auctionresult--vlaminck-maurice-de-1876-1958-rue-de-village-sous-la-neige1461825.htm

Julius von Klever (1850-1924)

Painting: "Naissaar Winter", 1881

Private collection.

https://www.liveauctioneers.com/item/36886630_julius-von-klever-1850-1924-naissaar-winter 
René Magritte (1898-1967)

Painting: "Nocturne", 1925

Magritte Museum, Brussels

http://www.mattesonart.com/Data/Sites/1/magritte/Nocturne\%201925\%200il.jpg

Painting: "The Difficult Crossing" (La traversée difficile), 1926

Private collection.

https://en.wikipedia.org/wiki/The_Difficult_Crossing

Maurits Cornelis Escher (1898-1972)

Etching: "The Second Day of the Creation", 1925

http://www.wikiart.org/en/m-c-escher/the-2nd-day-of-the-creation

Fernando Botero (1932- )

Paintings: "Earthquake in Popayán" (Terremoto en Popayán), 1999

Museo Botero del Banco de la Republica, Bogotá

https://uk.pinterest.com/pin/351280839663342636/

https://uk.pinterest.com/pin/343751384031901285/

Bernardo Bellotto (1721-80)

Painting: "The Ruins of the Old Kreuzkirche in Dresden", 1765

Gemäldegalerie, Dresden

http://www.wga.hu/html_m/b/bellotto/2/bello214.html

Renato Guttuso (1912-87)

Painting: "Stromboli", 1953

Collezione di arte moderna di Giuseppe Orlandi

http://www.artslife.com/2012/05/22/arte-moderna-e-contemporanea-da-wannenes-2/

Andy Warhol (1928-87)

Screenprints: "Vesuvius", 1980s

https://www.flickr.com/photos/mafaldablue/2149901452

\section{References}

Adams, F. D. (1938). The Birth and Development of the Geological Sciences. Baltimore: Williams \& Wilkins.

Alexander, D. E. (1982). Leonardo da Vinci and fluvial geomorphology. American Journal of Science, 282(6), 735-755.

Alexander, D. E. (2002). Nature's impartiality, man's inhumanity: reflections on terrorism and world crisis in a context of historical disaster. Disasters, 26(1), 1-9.

Brown, A. \& Mackie, V. (2015). Introduction: art and activism in post-disaster Japan. Asia-Pacific Journal: Japan Focus, 13(6), 1-6. 
Budrina, L. (2015). Wildfire in A.K. Denisov-Uralsky's canvases: destinies of the paintings. The Images of Elements in the Artistic Culture of Russia. Quaestio Rossica 2(1), 41-51.

Bulwer-Lytton, E. (1834). The Last Days of Pompeii (3 vols.). London: Richard Bentley. Büttner, N. (2006). Landscape Painting: A History (trans. Stockman, R.). New York: Abbeville Press.

Caffiero G. \& Samarine, I. (2013). Light, Water and Sky: The Paintings of Ivan Aivazovsky. London: Laurence King.

Chester, D. K. (2001). The 1755 Lisbon earthquake. Progress in Physical Geography, 25(3), 363-383.

Dissanayake, E. (2008). The arts after Darwin: Does art have an origin and adaptive function? In Zijlmans, K. \& van Damme, W. (eds) World Art Studies: Exploring Concepts and Approaches (pp. 241-263). Amsterdam: Valiz.

Dynes, R. R. (2000). The Lisbon earthquake in 1755: contested meanings in the first modern disaster. Tsulnfo Alert, 2(4), 10-18.

Falvo, P. G. (2014). The Madonna of the Goldfinch by Raphael: chamera of perception. In M. Ionnnides et al. (eds) Digital Heritage. Progress in Cultural Heritage: Documentation, Preservation, and Protection (pp. 706-715). Vol. 8740, Lecture Notes in Computer Science, Berlin: Springer.

França, J-A. (1983). Lisboa pombalina e o illuminismo. Lisbon: Bertrand.

Guidoboni, E. \& Comastri, A. (2005). Catalogue of Earthquakes and Tsunamis in the Mediterranean Area from the 11th to the 15th Centuries. Rome: Istituto Nazionale di Geofisica e Vulcanologia.

Koppenleitner, V. F. (2010). L'arte di Sconvolgere: sulla rappresentazione di terremoto e rovina nella pittura murale del trecento. L'esempio degli affreschi di Sant- 
Agostino a Rimini. In Matheus, M., Piccinni, G., Pinto, G. and Varanini, G. M. (eds) Le calamità ambientali nel tardo Medioevo europeo: realtà, percezioni (pp. 87110). Florence: Firenze University Press.

Murphy, A. H. (1996). The Finley affair: a signal event in the history of forecast verification. Weather Forecasting, 11(1), 3-20.

Özgenel, L. (2008). A Tale of Two Cities: In Search of Ancient Pompeii and Herculaneum. Journal of the Faculty of Architecture 2008/1 (pp. 1-25), Çankaya Ankara, Turkey: Middle East Technical University.

Perry, R. W. \& Quarantelli, E. L. (eds) (2005). What is a Disaster? New Answers to Old Questions. Philadelphia: Xlibris Press.

Sanquirico, C. (c. 1830). L'ultimo giorno di Pompei. Getty Research Institute, 93B15110, Pacific Palisades, California: J. Paul Getty Museum.

Scandone, R., Giacomelli, L. \& Fattori Speranza, F. (2008). Persistent activity and violent strombolian eruptions at Vesuvius between 1631 and 1944. Journal of Volcanology and Geothermal Research, 170(3-4), 167-180.

Shlain, L. (2014). Leonardo's Brain: Understanding Da Vinci's Creative Genius. New York: Lyons Press.

Shrady, N (2009). The Last Day: Wrath, Ruin, and Reason in the Great Lisbon Earthquake of 1755. Harmondsworth, UK: Penguin.

Voltaire, F. (2006, 1st edition 1759) Candide, or Optimism (trans. T. Cuffe). Harmondsworth, UK: Penguin Classics.

Wood, C. (1999). Victorian Painting. London: Wiedenfield \& Nicolson. 